\title{
Blended Learning System in Civic Education Courses to Develop Humanity Literacy
}

\author{
Kusnadi Kusnadi 1,*, Sapriya Sapriya ${ }^{2}$, Dasim Budimansyah ${ }^{3}$, Abdul Aziz Wahab ${ }^{4}$ \\ ${ }^{1}$ Universitas Terbuka, Indonesia \\ 2,3,4 Universitas Pendidikan Indonesia, Bandung, Indonesia \\ ${ }^{*}$ Corresponding author.Email: kusnadipkn@gmail.com
}

\begin{abstract}
Humanity literacy is the end of data and technology literacy because $21^{\text {st }}$ century learners are human resources who are literate with data and technology and can use them for a nobler life. Civic Education has a central role in building the quality of education in Indonesia, especially the development of human literacy. However, so far, it has experienced obstacles in the implementation process. Blended Learning is one of the best systems for Learning, from transition classes to e-learning. This method is very effective in increasing student involvement in interacting and reviewing information outside the classroom. The model impacts students' ability to develop human literacy in the use of data and technology. The method used in the analysis of this discussion is a literature review. Humanity literacy will be more successful with lesson plans that integrate various methods, teaching models, and learning styles and the use of various choices of media for discussion between facilitators and students.
\end{abstract}

Keywords: Blended Learning, Civic Education, Humanity Literacy.

\section{INTRODUCTION}

Human literacy is the control center of data literacy and technology. where learners as managers and controllers of data and technology are used for a more noble and dignified life. As an example, in modern times, someone who is data and technology literate has a leadership and teamwork spirit, cultural intelligence and does not abuse his potential as a human being. There are two essential qualities of desire, the first is related to the physical body, which is called animal nature, and the second is related to the mental (mind).

Desires associated with the human body include overeating, smoking, drinking alcohol, consuming narcotics, etc. The desires associated with the body only affect the person concerned, such as obesity, lung cancer, and kidney and liver damage. However, mentalassociated desires, such as the desire to accumulate as much wealth as possible to justify all means, through corruption, gambling, and even shamanic practices will affect many people, including all levels of society, an entire country, or even a group of countries in the world [1]. As the culmination point of the new literacy of the $21^{\text {st }}$ Century, human literacy will lead to a more dignified life with knowledge, skills, and an attitude of gratitude for the gift of life from the Almighty.

Human literacy means that a person has a good character which is interpreted the same as morality. Even morality touches the deepest part of the human heart, not just ordinary behavior, let alone just following general trends. Suppose someone is said to be of good character, for example. In that case, the expression of the deepest heart is manifested in his good attitude and behavior, sincere and sincere, not making it up or making it up. Sincerity is manifested in gestures, speech, facial expressions, and other body language. Students who have good character are the estuaries of national education goals [2]. This is what supports the following mandate of the Law on the National Education System:

"National education functions to develop capabilities and shape the character and civilization of a dignified nation in the context of educating the nation's life, aiming at developing the potential of students to become human beings who believe and fear God Almighty, have noble character, are healthy, knowledgeable, capable, creative, independent, and become a democratic and responsible citizen" (Article 3 of Law No. 20 of 2003).

To implement Article 3 of Law Number 20 of 2003, the government builds character education programs both nationally and within the scope of the education unit. This program implemented four pillars: teaching and learning activities in the classroom, daily activities in the culture of the education unit, and co-curricular and/or extracurricular activities. As well as activities at home and in the community [3]. In this context, the academic unit is an institution that plays a vital role in internalizing through providing understanding, habituation, and standardization of character. The implementation of this kind of role indicates that the school is a character institution [1].

Citizenship Education has a central role in building the quality of education in Indonesia. However, so far, it 
has had obstacles in the implementation process. The obstacles experienced by civic education so far are the quality of educators who do not four competencies (professional, pedagogic, social, and personality), and less creative learning methods (always use the lecture method) (Neufeld \& Davis, 2010). Since the Old Order, then the New Order until after the reform of Citizenship Education, it has not shown an optimal role in building the nation's character. Citizenship Education often draws criticism from various parties in academia, government, and the general public. On the other hand, the government's efforts since Citizenship Education subjects have used Civics have always tried to make Citizenship Education able to build students' knowledge, skills, and character. However, so far, it has not shown maximum results [4].

Constraints experienced by Civic Education same as previous years, namely still prioritizing the cognitive aspect, creating critical and responsible studentship hamet been realized [5]. Based on the author's observations when teaching Civic Education Courses, students assume that Civic Education is boring Learning because it always prioritizes theory and is not applicable. Most students assume that Civic Education is a formality course and only as a requirement for graduation. This assumption leads to a conclusion that Civic Education in the eyes of students is an unimportant course. It is a big blow for Civics Education lecturers because their courses are considered unimportant and only a graduation requirement. This phenomenon is an evaluation for the government to continuously improve the quality of education [6].

Blended Learning provides solutions to develop cognitive, affective, and psychomotor aspects. This system involves more students playing an active role through discussion or analyzing information outside the face-to-face class. Blended Learning is also a future learning system [7].

Blended Learning is a solution to overcome the weaknesses of face-to-face learning and online learning, namely there is still direct interaction between lecturers and students and between other students. This process makes feelings stronger, while the weaknesses of face-toface learning where the learning process is limited by space and time can be overcome online so that the results are more optimal.[8].

\section{THEORETICAL REVIEW}

\subsection{Blended Learning System}

The Blended Learning model combination of the advantages of learning carried out face-to-face and virtually. According to Semler (2005) [9].

"Blended Learning combines the best aspects of online Learning, structured face-to-face activities, and real-world practice. Online learning systems, classroom training, and on-the-job experience have major drawbacks by themselves. The blended learning approach uses the strengths of each to counter the others' weaknesses."

Blended Learning is combined various modes of delivery, teaching models, and learning styles, introducing various choices of dialogue media between the facilitator and the person being taught [10]-[13]. Blended Learning is also a combination of face-to-face teaching and online teaching, but more than that, as an element of social interaction [14]. Blended Learning is learning that is supported by a combination of effective methods. The advantages of using blended learning as a combination of face-to-face teaching and online teaching, as a social interaction, include:

1. There is interaction between teachers and students

2. Teaching can be online or face-to-face

3. Combining instructional modalities,

4. Combining learning methods [15], [16].

Humanity literacy is the human ability to accommodate, manage data and technology literacy in social, cultural, and philosophical contexts relevant to human values improve the quality of life, create happiness, and ensure sustainable development and peace.

Humanity literacy is important in surviving in this era, the goal is that humans can function well in the human environment and can understand interactions with fellow humans [17]-[19]. Human literacy is the end of data and technology literacy, because 21 st century learners prioritize humans who are able to manage data and technology for a nobler life.[20]. This interaction can be seen in the world of education, especially in the school environment. For this reason, the current task of the world of education through the learning process is not only to emphasize the strengthening of old literacy competencies, but also to strengthen new literacy that is integrated with strengthening the competence of scientific fields and expertise or professions [21], human literacy that is is currently an implementation trend in the face of the industrial revolution 4.0 [22], [23].

To be able to create human literacy,civic literacy in the $21^{\text {st }}$ Century is also needed, which is identified as having everal kinds of characteristics that young citizens, must possess:

1. Citizens who are active and participate effectively in government (politics).

2. Implement citizenship rights and obligations at local, national and global levels

3. Understand the local and global implications of community decisions

4. Apply $21^{\text {st }}$ century skills to make smart choices as citizens

5. Proficient in academic and interdisciplinary knowledge, environmental literacy such as; finance, economics, business and entrepreneurial literacy; and health awareness,

6. Have global competence and $21^{\text {st }}$ century skills, 
7. Able to participate safely, intelligently, productively and responsibly in the digital world [21], [24], [25].

Meanwhile, Wagner (2010) and the Change Leadership Group from Harvard University identified civic literacy in the 21 st Century which emphasizes the the following seven (7) skills: (1) critical thinking, (2) leadership, (3) adaptability, (4) entrepreneurial spirit, (5) able to communicate effectively, (6) able to access and analyze information, and ( 7) have an innovative curiosity[26].

Humanity literacy is the end of data and technology literacy because essentially a 21 st century learner is a human resource who is data and technology literate and is able to use it for a nobler life. For example, in the context of modern times, someone who is data and technology literate has leadership and teamwork, cultural intelligence, Character Learning Project to Develop New Literacy in the $21^{\text {st }}$ Century and does not abuse his potential as a human being based on bad desires. There are two basic natures of desire, the first is associated with the physical body which is called the animal nature, and the second is related to the mental (mind) which is called the Satanic nature. Desires associated with the human body such as overeating, smoking, drinking alcohol, consuming illegal drugs, narcotics and so on. The desires associated with the body only affect the person concerned, such as obesity, lung cancer, and kidney and liver damage. However, mental-associated desires, such as the desire to accumulate as much wealth as possible so that it justifies all means, through corruption, gambling, and even shamanic practices will affect many people, including all levels of society, an entire country or even a group of countries in the world. Budimansyah, 2018). As the culmination of the new literacy of the 21 st Century, if one has human literacy, it will actually lead to a nobler life with knowledge, skills, and an attitude of gratitude for the gift of life from the almighty [20].

\subsection{Citizenship Education as General Education}

Citizenship education is one of general education. According to RO Hand and D. Biona in Winataputra (2014) General education is the process of fostering a whole person, namely a human who is balanced in knowledge, ability to think, feel, awareness of his skills, healthy human being spiritually (mentally) and physically, humans who are able to harmonize with society, understand other people well, are responsive to the needs of others as good partners, humans who can adjust / harmonize personally, understand themselves, calm and reasonable in overcoming real situations. Meanwhile, according to Wolfgang Klafki General Education is the development of human abilities, comprehensive education to improve intellectual-rational abilities (cognitive), fully aware emotional (affective) and skills in the broadest sense (cognitive-affective and psychomotor) and applies to all people in general [27].

\subsection{Humanity Literacy in the Perspective of Citizenship Education}

The industrial revolution has produced digital innovations that accelerate the global era that affects the pattern of human life. The era of the industrial revolution 4.0 requires new innovations to deal with it. At least a new literacy orientation is needed that does not only rely on old literacy, namely reading, writing and arithmetic, but moves on to data literacy, technology, and humanity. Technological skills in society are not only limited to technical skills, but also extend to ethical skills. The Industrial Revolution 4.0 has resulted in digital innovations that accelerate the global era that affects the pattern of human life. Digital technology is considered to outperform the role of humans as cultural producers which causes a tendency to feel alive in a void of meaning. Thus not everyone is able to dive into this rapidly changing life.

According to Budimansyah et al (2019), the current condition is entering an era of disruption. The era of disruption can create opportunities as well as be a threat. Therefore, in order to be able to take advantage of opportunities and be able to face these threats, every component of society should master new literacy, in addition to the old literacy that has been mastered. New literacy in the $21^{\text {st }}$ century disruption era is data literacy, technological literacy, and human literacy [20]. Data literacy is related to the ability to use, explore meaning, apply it in various fields of life. Technological literacy is related to the ability to use technology as well as to understand its impact. Human literacy is related to the ability to understand human nature and attitudes as a subject with many characters.

Humanity literacy which is an ability to think to utilize and manage sources of knowledge which is then poured into wise behavior. Literacy in national and human values will create citizen literacy. According to the Center for Testing and Development of the Ministry of Education and Culture and Yogyakarta State University, a citizen is required to have knowledge of; 1) Humans as zoon politicon; 2) Values, Norms and Values; 3) Norms in Society; 4) Nation and State; 5) Constitution; 6) Political Institutions; 7) Nationality; 8) Democratic Political System; 9) The rule of law and its enforcement; 10) Human Rights; 11) Indonesia's role in international relations; and 12) National Identity. Such literacy must be directed to form a good character [28]. This describes a good character which has 3 (three) components, namely; knowledge about morals (moral knowing), feelings about morals (moral feeling), and moral actions (moral action). All of these components are needed in order to understand, feel and apply the values of virtue[29].

Based on various literature, that conventionally, Learning that takes place today still relies on the teacher as an information center so that the teacher is considered as the primary determinant in the success of the learning process. As a Citizenship Education educator in character 
building and character building includes, among others; 1) Teachers have a role in fostering students' faith and piety through worship direction, fostering tolerance, internalizing religious values, and moral development; 2) The teacher plays a role in fostering good manners by means of; directing in speaking politely and ethically, acting politely and ethically, respecting and appreciating each other, daring to be responsible. In addition, there are also several weaknesses, among others; 1) The teacher has not acted as a facilitator; 2) The teacher is not a learner; 3) Class management is not optimal; d) learning has not been well planned; e) Teachers have not been able to become role models; f) The teacher has not been able to act as a motivator [30]

\section{CONCLUSION}

Literacy is an ability to know knowledge that will include all skills regarding how to think and use knowledge sources, which will then be processed or implemented. Literacy in national and human values will then transform into citizen literacy. According to the Center for Testing and Development of the Ministry of Education and Culture and Yogyakarta State University, a citizen is required to know; 1) Humans as zoon politicon; 2) Values, Norms and Values; 3) Norms in Society; 4) Nation and State; 5) Constitution; 6) Political Institutions; 7) Nationality; 8) Democratic Political System; 9) The rule of law and its enforcement; 10) Human Rights; 11) Indonesia's role in international relations; and 12) National Identity (Lickona, 2013). Humanity literacy must be directed to form a good character. Describing good character has 3 (three) components, namely, knowledge about morals (moral knowing), feelings about morals (moral feeling), and moral actions (moral action). All components are needed to understand, feel, and apply the values of virtue, which leads to a noble life.

\section{REFERENCES}

[1] D. Budimansyah, H. S. Hood, dan I. Nurulpaik, 'Strengthening students' character as authentic learners: Effects of advanced school leadership and boost learning," in Proceedings of the Annual Civic Education Conference (ACEC 2018), 2018, hal. 327-332, doi: https://doi.org/10.2991/acec-18.2018.75.

[2] D. Budimansyah dan K. Suryadi, PKN dan masyarakat multikultural. Bandung: Program Studi Pendidikan Kewarganegaraan Sekolah Pascasarjana Universitas Pendidikan Indonesia, 2008.

[3] D. Budimansyah, "Peningkatan mutu pendidikan melalui penguatan partisipasi masyarakat," Educationist, vol. 2, no. 1, hal. 56-63, 2008.

[4] P. Widiatmaka, "Kendala Pendidikan Kewarganegaraan dalam membangun karakter peserta didik di dalam proses pembelajaran," $J$. Civ. Media Kaji. Kewarganegaraan, vol. 13, no.
2, hal. 188-198, 2016, doi: 10.21831/civics.v13i2.12743.

[5] F. S. Sofyan dan D. Sundawa, "Hubungan mata kuliah pendidikan kewarganegaraan," J. Pendidik. Ilmu Sos., vol. 24, no. 2, hal. 185-199, 2015.

[6] M. Murdiono, "Pendidikan kewarganegaraan untuk membangun wawasan global warga negara muda," J. Cakrawala Pendidik., vol. 3, no. 3, hal. 349-357, 2017, doi: 10.21831/cp.v3i3.2379.

[7] W. Yu dan X. Du, "Implementation of a blended learning model in content- based EFL curriculum," Int. J. Emerg. Technol. Learn., vol. 14, no. 5, hal. 188-199, 2019, doi: 10.3991/ijet.v14i05.8546.

[8] M. Sari, "Blended learning model pembelajaran abad ke 21 di perguruan tinggi," J. Ta'dib, vol. 17, no. 2, hal. 126-136, 2016.

[9] P. . Jessica K. Beaver, P. D. ttan Hallar, dan L. Westmaas, Blended learning defining models and examining conditions to support implementation. Philadelphia: PERC Research Brief, 2014.

[10] A. C. Ali Alammary, Judy Sheard, "Blended learning in higher education: Three different design approaches," Australas. J. Educ. Technol. 2014, 30(4)., vol. 30, no. 12, hal. 440-465, 2014.

[11] F. Z. Azizan, "Blended learning in higher education in Malaysia," in Proceedings of Regional Conference on Knowledge Integration in ICT 2010 (2010) 454-466, 2010, vol. 9, no. 1, hal. 454-466.

[12] M. OLIVER dan K. TRIGWELL, "Can 'blended learning' be redeemed?," E-Learning, vol. 2, no. 1, hal. 17-26, 2005, doi: 10.2304/elea.2005.2.1.2.

[13] A. H. K. Yuen, L. Deng, R. Fox, dan N. J. Tavares, "Engaging students with online discussion in a blended learning context: Issues and implications," in Lecture Notes in Computer Science (including subseries Lecture Notes in Artificial Intelligence and Lecture Notes in Bioinformatics), 2009, vol. 5685 LNCS, no. August 2009, hal. 150-162, doi: 10.1007/978-3642-03697-2_15.

[14] J. Bhowmik, D. Meyer, dan B. Phillips, "Using blended learning in postgraduate applied statistics programs," Turkish Online J. Distance Educ., vol. 20, no. 2, hal. 64-77, 2019.

[15] U.-D. Ehlers, "Quality in e-learning from a learner's perspective," Distances médiations des savoirs, vol. 1, no. 23, hal. 1-7, Agu 2018, doi: 10.4000/dms. 2707.

[16] K. M. Oliver dan D. T. Stallings, "Preparing teachers for emerging blended learning environments," J. Technol. Teach. Educ., vol. 22, no. 1, hal. 57-81, 2014, [Daring]. Tersedia pada: https://www.learntechlib.org/p/112374/.

[17] D. E. Alvermann, "Effective literacy instruction for adolescents," J. Lit. Res., vol. 34, no. 2, hal. 
189-208, 2002, doi: $10.1207 /$ s15548430j1r3402_4.

[18] S. Diaz dan A. Walsh, "Promoting evidencebased practice and information literacy through an undergraduate nursing journal club," Pennsylvania Libr. Res. Pract., vol. 6, no. 1, hal. 23-38, Mei 2018, doi: 10.5195/PALRAP.2018.171.

[19] S. Qiyou, "Research on humanistic literacy education for higher vocational student majoring in art design," in 2016 International Conference on Humanities Science, Management and Education Technology (HSMET 2016) ISBN: 978-1-60595-394-6, 2017, no. hsmet, hal. 115119, doi: 10.12783/dtssehs/hsmet2016/10265.

[20] D. Budimansyah, N. Suharto, dan I. Nurulpaik, Proyek Belajar Karakter Untuk Mengembangkan Literasi Baru Abad 21, vol. 1. Bandung: Gapura Press, 2019.

[21] J. Khlaisang dan P. Koraneekij, “Open online assessment management system platform and instrument to enhance the information, media, and ICT literacy skills of 21 st century learners," Int. J. Emerg. Technol. Learn., vol. 14, no. 7, hal. 111-127, 2019, doi: 10.3991/ijet.v14i07.9953.

[22] S. Deliani, S. Sulistyawati, dan B. Kurniawan, "Pembentukan karakter melalui literasi dari aspek satra dan budaya di Desa Manik Maraja Kec Sarimatondang Kabupaten Sidamanik," in Prosiding Seminar Nasional Hasil Pengabdian, 2018, hal. 156-160, [Daring]. Tersedia pada: https://e-

prosiding.umnaw.ac.id/index.php/pengabdian/ar ticle/view/109.

[23] Sanjayanti, Qondias, Wardana, dan Darmayanti, "Diagnosa literasi humanistik dalam model pembelajaran konstruktivis pada mahasiswa Politeknik Ganesha Guru," in Seminar Nasional Riset Inovatif 2018, 2018, hal. 92-96.

[24] Partnership for 21st Century Skills, Reimagining citizenship for the 21st century: a call to action for policymakers and educators. 2014.

[25] J. Salpeter, " 21 st century skills: will our students be prepared?," 2008 . .

[26] S. Zubaidah, "Keterampilan abad ke-21: Keterampilan yang diajarkan melalui pembelajaran," J. Pendidik., vol. 2, no. 2, hal. 117, 2016, doi: 10.1021/acs.langmuir.6b02842.

[27] U. S. Winataputra, Pendidikan kewarganegaraan dalam perspektif internasional. Bandung: Widya Aksara Press, 2014.

[28] Lickona, Educating for character. Jakarta: Bumi Aksara, 2013.

[29] M. N. Somantri dan U. S. Winataputra, Disiplin pendidikan kewarganegaraan: Kultur akademis dan pedagogis, Edisi pert. Bandung: Laboratorium Pendidikan Kewarganegaraan Universitas Pendidikan Indonesia, 2017.

[30] Fatahillah, "Pembekalan literasi nilai kebangsaan dan kemanusiaan bagi calon guru secara andragogi sebagai bagian gerakan penumbuhan budi pekerti di sekolah dasar," in Prosiding Konferensi Nasional Kewarganegaraan III, 2018, no. November, hal. 161-166. 